\title{
Presumed consent or contracting out
}

\author{
Charles A Erin and John Harris University of Manchester, Manchester
}

In the United Kingdom, we have become habituated to an opting-in system of cadaveric organ procurement. It is becoming of increasing concern that this system is failing to meet the demand for organs for transplantation, with 5,349 people on waiting lists for solid organ transplants at the end of $1998 .{ }^{1}$ Manifestly, such a tragic statistic alarms us all, and calls for urgent attention, and, perhaps, for radical action. And, at one level, this is what we have witnessed in the British Medical Association's (BMA) recent reversal of its historical opposition to a system of so-called presumed consent for the procurement of cadaver organs. ${ }^{2}{ }^{3}$ The BMA's overwhelming vote in favour of changing to an opt-out system at its annual conference in early July followed, almost immediately, publication of the results of a government survey which showed a lack of public support for such a system, ${ }^{4}$ and it thus came as no great surprise that the government later rejected the BMA's proposal. ${ }^{5}$ Bad timing perhaps, but, whilst any necessary change in legislation might be minimal, if the United Kingdom was to adopt a system of cadaveric organ donation based on presumed consent, this would clearly represent a major overhaul of social policy in this area, and an overnight tidal change in public opinion is hardly to be expected.

For the sake of argument, let us accept the general view that presumed consent legislation does increase the yield of cadaver organs for transplantation. ${ }^{78}$ However, there is more than efficiency to consider, and here we will be concerned with arguments from moral principle, not from statistics. ${ }^{9}$

\section{Presumed consent is a fiction}

The first point to note is that presumed consent is a fiction. Without the actual consent of the individual, there is no consent. This is an important point in the context of cadaver organ procurement, particularly in the face of legal instruments adopted in various jurisdictions to increase the number of cadaver organs available for transplantation.
Many see presumed consent as synonymous with contracting out. ${ }^{10}$ And it is, of course, intuitively attractive to do so. The underpinning message of the system to which the conflation of these terms refers is something like this: "unless you make it clear during your lifetime that you would refuse to donate organs on death, we will presume that you consent to organ removal, even though you do not actually consent". Even ignoring the question of whether presumed consent represents a contradiction in terms, there is a significant and worthwhile distinction to be drawn between the notion of presumed consent and contracting or opting out, and the distinction speaks to what is at the basis of social policy in this area, and how that policy sells itself, and is interpreted.

Are we not, in adopting the language of consent, attempting to disguise what we are actually doing in a way which, however well motivated, appeals to the now well recognised principle of respect for individual autonomy? In reality, by presuming consent, we are acting against that principle; we are being disrespectful of individual autonomy. However it might be perceived, in formalising a contracting-out approach for the removal of organs from cadavers, we are, in essence, articulating a particular society's view of what it is morally supportable to do with the body of a dead person, ${ }^{11}$ where that person has not consented prior to death ${ }^{12}$ to such treatment of her body after death. Effectively, we are saying: "where citizens do not explicitly make known their refusal to donate organs when dead, we feel that it is morally justifiable to remove them in order to improve the quality of life of living citizens and to save lives". It seems that, however we care to represent it, if we are prepared to remove organs from the dead in the absence of prior consent, we do so simply because we believe it is the right thing to do; and we believe that it is the right thing to do because we know it is in the best interests of those patients in need of an organ, and that not to remove these organs would be to harm those patients and to 
respect no values of moral significance comparable to respect for the lives that are at risk..$^{13}$

Two final points seem apposite. Presuming consent is an affront to the moral principle that is the foundation of consent itself. That said, as fictions go, this is a very popular fiction, having the support of, for example, the Declaration of Helsinki, and the Council for International Organisations of Medical Sciences (CIOMS) guidelines. ${ }^{1516}$ Nevertheless if we are to presume anything, we should presume that people would wish to do the morally right thing in the particular situation. In the case of cadaver organs this is certainly to make them available for life-saving or life-enhancing use.

We must also remember that while people talk of their ownership of their own organs and their rights to dispose of them as they wish, the normal incidents of ownership are lacking in the case of cadaver transplantation. There is no one who gets to keep the organs. If they don't go for donation, the worms or the fire, or sometimes the coroner, will have them. Of course there are such things as wills for disposal of property after death, but there are also such things as death duties. Perhaps best of all would be to think of cadaver donation in such terms, as a duty the dead owe to the living, which costs them little or nothing to pay and which does huge amounts of good.

\section{Acknowledgement}

We are indebted to Phil Dyer and John Evans for useful discussion of the statistics mentioned in reference 1 .

Charles $A$ Erin, BSc (Wales), MSc (London), MSc and PhD (Manchester), is Head of the Centre for Social Ethics and Policy, and Senior Lecturer in Applied Philosophy at the University of Manchester, and a Fellow of the Institute of Medicine, Law and Bioethics. Fohn Harris, BA (Kent), DPhil (Oxford), is Sir David Alliance Professor of Bioethics and a Director of the Institute of Medicine, Law and Bioeth$i c s$ at the University of Manchester. Address for corre- spondence: Dr Charles A Erin, Institute of Medicin Law and Bioethics, University of Manchester, Oxford. Road, Manchester M13 9PL, United KingdonfP Tellfax: + $441612753468 /$ 3473. E-ma Charles.Erin@man.ac.uk

\section{References and notes}

1 United Kindom Transplant Support Service Authorify (UKTSSA) figures, taken from http://www.argonet.co.uF users/body/DoH.html. The figure of 5,349 represents the active waiting list; including the suspended figure, the total is 6,5024 And this is despite there having been 2,694 solid orgafr transplants from cadavers during 1998.

2 Anonymous. Doctors back organ donation reform. BBC Nez Online. http://news.bbc.co.uk/hi/english/health/newsid_38900 9 389043.stm posted $8 \mathrm{July,} 1999$.

3 Beecham L. BMA wants presumed consent for organ donors. British Medical fournal 1999;319:141.

4 Department of Health. Press release 1999/0405. Survey shovis that public prefers existing organ donor scheme. 2 Jul 1999.

5 Anonymous. Opposition to changing organ donor scheme $B B C$ News Online. http://news.bbc.co.uk/hi/english/healtF newsid_384000/384401.stm posted 3 July, 1999.

6 Anonymous. Organ donor reform rejected. BBC News Online. http://news.bbc.co.uk/hi/english/health/newsid\%5F396000/ 396430.stm posted 16 July, 1999.

7 Compare with: Sells RA. Radical options for improving the supply of cadaveric organs, presented at Multi-cultural ethical issues in transplantation. International Conference, Institute of Medicine, Law and Bioethics (IMLAB), University of Maeo chester, and University of Tel Aviv, Manchester, 21-22 Febro ary, 1999 (unpublished observations).

8 Though, as Michielsen warns, we should be careful in compas ing national statistics. See Michielsen P. Informed or presume consent legislative models. In Chapman JR, Deierhoi $M$ ane Wright C, eds. Organ and tissue donation for transplantatiog London: Arnold, 1997:349-354, esp. 349.

9 For what it is worth, however, the successful Spanis experience suggests that a change of law alone is insufficienf and, whether we are to go this route or not, it seems that greate resourcing for transplant co-ordinators, for example, is calle for.

10 For example, see reference 8:344

11 A dead person? There is something self-contradictory abow

12 This. is no relevant, reliable advance directive, whether in the form of a living will, or a record on the National Organ Donor Regist or an organ donor card.

13 Compare with Harris J. Research, transplantation and the dut to others. (unpublished observations)

14 We assume the moral and causal symmetry of acts an omissions. See Harris J. Violence and responsibility. London. Routledge \& Kegan Paul, 1980.

15 World Medical Association. Declaration of Helsinki, as amended by the 48th General Assembly, October 1996: basic principto 11.

16 Council for International Organisations of Medical Sciencis (CIOMS) in collaboration with the World Health Organization (WHO). International ethics guidelines for biomedical research involving human subjects. CIOMS and WHO: Geneva, 1993 guideline 1 . 